\title{
A Sustainability Lighthouse-Supporting Transition Leadership and Conversations on Desirable Futures
}

\author{
John Holmberg * (1) and Johan Larsson \\ Division Physical Resource Theory, Chalmers University of Technology, SE-412 96 Gothenburg, Sweden; \\ johan.larsson@chalmers.se \\ * Correspondence: john.holmberg@chalmers.se; Tel.: +46-31-772-3145
}

Received: 9 July 2018; Accepted: 20 October 2018; Published: 23 October 2018

\begin{abstract}
Central in leadership for sustainability transitions is the capability to create transformative momentum in a sustainable (desirable) direction, calling for meaningful conversations on sustainable futures. The aim of this study is to develop a conceptual framework to inspire and support such conversations. A qualitative literature review of sustainability conceptualizations was conducted, followed by a thematic analysis. The resulting framework consists of an overarching question and an accompanying set of categories for four sustainability dimensions: the social, the economic, the ecological, and 'human needs and wellbeing'. Furthermore, the framework is visualized as a lighthouse for pedagogical reasons. We foresee that the lighthouse might be of value in processes guiding socio-technical transitions towards sustainability in three different ways: (1) by attempting to bridge the issue of 'transition' with that of 'sustainability'; (2) as part of a backcasting process; and (3) modes of transdisciplinary research where relevant actors take part in the conversation. The study is related to over 20 years of experience from working with a backcasting approach engaging with sustainability transitions in a variety of processes. We invite further dialogue on how one may approach the concept of sustainability to inspire and support conversations on sustainable futures.
\end{abstract}

Keywords: sustainability; Agenda 2030; leadership; transitions; futures; backcasting; transdisciplinarity

\section{Introduction—Leadership for Sustainability Transitions}

It is recognized in the United Nations Agenda 2030 for Sustainable Development that "bold and transformative steps ... are urgently needed to shift the world on to a sustainable and resilient path" [1] (p. 1).

Discussions around transformative change to achieve sustainability are of central attention in sustainability transitions research [2-6]. Here, such change is understood as 'system innovations' or 'transitions', involving fundamental processes of change on a level of systems in society, where unsustainable systems are phased out and more sustainable configurations emerge. Transitions are considered long-term, open-ended, co-evolutionary, multi-actor processes, inherently complex, uncertain, and ambiguous [4,7-10]. Moreover, transitions are assumed necessary to achieve sustainability in time in e.g., current unsustainable energy-, mobility-, agrifood-, and healthcare systems.

It is acknowledged that transitions cannot be planned, but they can be influenced. Purposive engagement with transitions includes reflexive modes of governance that are characterised by experimentation and learning-by-doing [11-14]. These modes share the view that navigating transitions is to a large extent about entering and exploring the unknown.

Transitions literature often contrasts processes of system optimization with system innovation. Processes of optimizing and refining what currently "is" follow a different logic compared to those of experimenting, which often call for different kinds of leadership. Metaphorically, the former can 
be considered going on a charter trip (cruise), whereas the latter joining an expedition (adventure) [15]. In a charter trip, current structures, routines, and budget frames, etc. provide support, whereas in an expedition, they may be seen as barriers. Goals, targets, steering, controlling, measuring, and following up are typically associated with a charter trip; guiding principles, trust, autonomy, flexibility, creating space for new initiatives, reflection, and learning (not least from mistakes) are central elements in an expedition. A charter trip regards organization as central to a leadership concerned with decision-making. In an expedition the question (the challenge) takes the centre stage; relevant actors across organizations are invited to explore and co-create together, resembling a leadership that is more concerned with facilitation. In the charter, emphasis is placed on problem solving and solution implementation, whereas in an expedition it is on creating desirable futures.

Given these distinguishing elements, leadership for sustainability transitions does not suggest that charter leadership be replaced by expedition leadership. Rather, it acknowledges that they co-exist and complement each other for mutual learning. Experimentation is not to be done in isolation as an expedition, but it should relate to and respect ongoing processes [16,17]. Likewise, activities more oriented towards the charter may benefit from transformative experiments if they are aligned on a higher level, e.g., through long-term visions and principles.

Even with the insight that expedition leadership is about complementing rather than replacing charter leadership, issues of resource scarcity, goal conflicts, and uncertainty may encourage a tendency to resort to traditional routines and practices. This particular study can be seen from the perspective of understanding conditions for and capabilities of leadership processes that facilitate experimentation.

We argue that the capability to create transformative momentum in (a shared understanding of) a desirable direction is an essential element in leadership for sustainability transitions. This in turn calls for meaningful conversations on desirable futures. The value of leadership processes starting from the future has been emphasized by others [18-20], where Stewart [18] put it in the following words: "what is can be a great barrier to what could be. Those who want to move forward through bold and effective change, should begin at the end-with where they want to be" (p. 98). Compelling visions of the future are also of central importance in the governance of transitions [11,21,22].

Since its launch, the concept of sustainable development has been commonly used by various actors at different scales to frame and discuss desirable futures. Yet, the concept is often criticized for its vague nature [23]. It may be no surprise that Agenda 2030, accompanied by 17 Sustainable Development Goals and 169 targets, has received notable attention for providing a contribution on areas that should be prioritized for global sustainability. Yet, the 17 goals stop short of mentioning what lies in the term sustainability.

Sustainability can be interpreted and approached in many different ways [24,25]. This particular study seeks to contribute with an understanding of "what" the concept may contain, with the intention of supporting conversations on desirable futures.

The issue of "what" sustainability is can be addressed by leaving the term either open to be dealt with in a process, or more closed and predefined. One example of the former is 'transition management', which to a large extent leaves it open for the participants to construct an understanding of sustainability in each particular setting [26]. 'Planetary boundaries' is one example of the latter, framing sustainability in the form of "boundary conditions" that function as biophysical thresholds that must not be transgressed [27].

This particular study seeks to approach sustainability in a balanced manner; leaving the term open to invite for conversations, while also inspiring and supporting them. We refer to this as the search for a balanced approach.

Having an open process acknowledges the essentially contested (political and normative) nature of sustainability [28]. Leaving the term open creates a "constructive ambiguity" that can serve as an invitation for those who share the concern about sustainability [29]. Yet, as sustainability is a complex and multi-faceted term, the way that conversations are held around it is far from straightforward. In addition to an open process, some inspiration and support may be beneficial to guide conversations 
in thinking beyond (escaping present unsustainable systems), thinking broader (considering several sustainability aspects in parallel), and thinking together (creating shared meaning of different concepts). Skillful facilitation is considered key for supporting various actors groups in such conversations [30]. The idea of an informed open-ended process has been put in the following words by Robinson [29], where sustainability

"... usefully can be thought of as the emergent property of a conversation about desired futures that is informed by some understanding of the ecological, social and economic consequences of different courses of action. This view acknowledges the inherently normative and political nature of sustainability, the need for integration of different perspectives, and the recognition that sustainability is a process, not an end-state." (p. 381)

Such a balanced approach to sustainability may be of special interest in backcasting [31-33], where conversations on desirable futures play a central role. This is further elaborated upon in Section 1.2.

\subsection{Study Aim}

The aim of this study is to create a conceptual framework with a set of categories to inspire and support conversations on sustainability. We look for categories fulfilling the following criteria: basic (seeking upstream 'first-order' mechanisms that are key for the dimension); sufficient (seeking to cover all major aspects of the dimension); and, non-overlapping (seeking internal homogeneity and external heterogeneity). These criteria build upon previous applications that are used in the development of socio-ecological principles for sustainability [34].

Such categories may be used to ask questions that inspire and support conversations on sustainability on different levels and scales (ranging from individuals via groups, organizations, and societies to humanity), with the capability of: thinking beyond present unsustainable systems; thinking broader about sustainability by considering several aspects in parallel; and, thinking together by creating shared meaning around different concepts. This includes conversations that cover major aspects of the issue at hand, that identify root-causes and separate means from ends (not least important in backcasting).

The categories can thereby not least contribute to the creation of a 'why', providing purpose and direction in the guidance of transitions. Such categories may also be used as a starting point in the formulation of more specific guiding principles.

\subsection{Study Context}

The framework may be applied in transdisciplinary processes where relevant actors take part of the conversation. Transdisciplinarity considers research a public good, with the ambition of creating socially robust knowledge in modes of co-production together with societal actors. Transdisciplinarity also opens up for mutual learning between researchers from different fields and between science and practice [35-39].

We expect that this framework can also function outside of academic environments, without direct involvement of researchers. Yet, it is important that researchers remain attentive to the relevance of such frameworks in relation to how the societal discourse develops.

Typically, conversations on desirable futures provide a natural starting point in backcasting approaches, which seek to frame desired futures and analyse how they might be achieved [31,33,40-42]. In particular, the framework sought after in this study may fit the procedure of backcasting from principles [32,41]. In relation to [32,41], a framework with a balanced approach to sustainability invites for a more open and inductive procedure where the understanding of sustainability is constructed in its particular time and place $[24,29,39]$.

This particular study is related to over 20 years of experience from working with a backcasting approach engaging with sustainability transitions in a variety of processes. In such processes, it is 
rewarding for the transformative momentum to provide purpose and direction in transitional processes, if one manages to stay in the "why" in an appropriate way [32,43].

\subsection{Outline of the Paper}

The structure of this paper is as follows: Section 2 provides a brief background on the concept of sustainability, including the first steps towards a conceptual framework. Section 3 presents the method used to arrive at a conceptual framework. Section 4 presents the results from the study, summarized in a conceptual framework presented in Section 5 . We then end the paper with a concluding discussion (Section 6).

\section{Towards a Conceptual Framework}

With the aim of creating a conceptual framework with a set of categories for each sustainability dimension, a starting point is taken in Brundtland's definition of sustainability as "meeting the needs of the present without compromising the ability of future generations to meet their own needs" [44] (p. 41). Alongside the popularization of this concept, three sustainability dimensions emerged: the social, the economic and the ecological (environmental).

The Brundtland notion represents an anthropocentric view of sustainability, which is a common starting point of most international agreements and sustainability initiatives [45], as well as a common source of critique. In this particular study, the main reason for starting from Brundtland's definition is its position in the international understanding of sustainability. It can also be noticed that an anthropocentric view does not necessarily mean that the intrinsic values in nature cannot be recognised [34,46].

Additionally, the three dimensions are commonly referred to and internationally adopted. Early referencing of the dimensions can be found in The Rio Declaration on Environment and Development [47], referred to as the "mutually reinforcing pillars of sustainable development" in the 2002 Report of the World Summit on Sustainable Development in Johannesburg [48] (p. 1).

Concurrently, there are ongoing debates [49-51] on whether to extend the three dimensions of sustainability to recognize cultural, political or institutional aspects. However, it is unclear if they should be recognized as explicit sustainability dimensions or considered/captured by the other dimensions. Until this point, they have not yet received the same status as the social, economic, and environmental in international agreements. For example, the recently launched Agenda 2030 refer to the social, economic, and environmental as the dimensions of sustainable development [1].

Dimensions of sustainability are also present in research contributions on the concept. In 1973, Daly [52] presented a hierarchical triangle of means and ends, with the four components of nature, economy, society, and human wellbeing, which were later developed by Meadows [53]. The triangle considers nature as an ultimate means at the bottom, economy and society as intermediate means and ends, and human wellbeing as ultimate ends on top, respectively. The same dimensions were later adopted in "the sustainability compass" by AtKisson and Hatcher [54], who claim no hierarchy between the dimensions, arguing that it is a matter of culture and perspectives.

Building on both UN processes and research perspectives, and with the intention of supporting transdisciplinary processes, the framework in this study considers four dimensions of sustainability. Social, economic, and ecological dimensions are supplemented by a fourth dimension of 'human needs \& wellbeing', as an explicit reference to the Brundtland definition. This choice is also motivated by two reasons. Firstly, human needs and wellbeing seek to cover what a desirable and good life implies. A clarification of what is considered desirable can provide purpose, motivation, and guidance in leading processes of change. Secondly, given the scale of current human activities on this planet, how human needs and their way of fulfilment are considered can have considerable implications on the social, economic, and ecological sustainability dimensions.

As has been highlighted in resilience research, the dimensions of sustainability cannot be understood as simple isolated entities. Rather, they are coupled, mutually dependent, and behave 
in non-linear ways [55-58]. The social, economic, and ecological sustainability dimensions can be understood as preconditions for guaranteeing human needs and wellbeing also in the future. Hence, they concern intra- and intergenerational justice, as well as achieving sustainability in coupled human-environment systems.

Building upon the aim of this study and the criteria described in the introduction, we are interested in conceptualizations and frameworks that have intended to capture central aspects of sustainability, with the ambition of covering all sustainability dimensions. In particular, it discusses frameworks interested in categories with a balanced approach. Numerous contributions with such ambitions exist, including systematic reviews and analyses building on larger sets of individual contributions [59-61].

We bring forward one such contribution towards ecological sustainability, and one towards human needs and wellbeing. Both are in line with the aim of the study, the criteria, and the search for a balanced approach. In Sections 2.1 and 2.2, we elaborate upon and motivate these choices.

Regarding the economic and social sustainability dimension, there are no evident contributions that fulfil our requirements. The contributions that exist bring forward different terms that point in different directions, including aspects directed towards both means and ends. This may partly be explained through differences in purpose, methodological approach and context of the respective study. We therefore explore these dimensions further in a systematic way through a qualitative literature review and thematic analysis (Missimer, Robèrt and Broman [62] used similar criteria as this particular study to categorize what they refer to as social sustainability. Missimer et al. aim at boundary conditions, resulting in the formulation "people are not subject to structural obstacles to: health, influence, competence, impartiality and meaning-making" (p. 48). There are good reasons for searching in that direction. However, this particular study seeks a balanced approach in which we do not go all the way to suggest guiding principles or boundary conditions. With our conceptualization of the four sustainability dimensions, the categories by Missimer et al. resemble aspects for the "human needs and wellbeing" dimension. The formulation "not structural obstacles ... " is with our conceptualization and understanding more related to the social and economic dimension. Since our aim is to inspire and support conversations on sustainability, we seek to make the social and economic dimension more explicit. Therefore, Missimer et al. is used as one important contribution among the others in the further analysis in this particular study).

The following subsections elaborate upon and motivate the choices of conceptualizations for 'human needs and wellbeing' and ecological sustainability, before presenting the thematic analysis of social and economic sustainability and resulting framework.

\subsection{Human Needs and Wellbeing}

The human needs dimension is acknowledged in Brundtland's definition of sustainability. This definition considers guaranteeing human needs in the present and the future to be central to sustainability. Therefore, both perceived needs and their means of attainment reflect the kind of life one wants to live, as well as the kind of world one wants to live in (or gets, as a consequence of these choices). We seek to capture the concept of human needs and wellbeing in the conceptual framework with the overarching question "what is a good life?".

To expand upon this question with a set of balanced categories, we bring forward the Human Scale Development (HSD) approach, consisting of nine fundamental human needs postulated by Max-Neef et al. [63]: Subsistence, Protection, Affection, Understanding, Participation, Idleness, Creation, Identity and Freedom. Transcendence is sometimes included in this list and, with subsistence as the only exception, no hierarchy is proposed to exist between the different needs. The needs are argued to remain the same over time and between cultures, however their way of satisfaction might differ [64].

It is worth mentioning other categorizations on human needs in this context. Maslow's hierarchy of needs [65]: Physiological, Safety, Love, Esteem, Self-actualization, where the satisfaction of a lower need was presumed to lead to an emergence of a higher order need. Doyal and Gough [66] instead bring forward the needs of Health and Autonomy to be the "conceptual and empirical preconditions for 
the achievement of other goals" (p. 15) (e.g., fulfilment of other needs). Health refers to both physical and mental health as "the most basic human need and the one which it will be in the interest of individuals to satisfy before any others" (p. 16). Autonomy refers to having an identity and a sense of self with freedom and agency to in achieving one's own goals. Note also the five categories put forward by Missimer et al. [62].

Further, the contribution by Max Neef et al. [63] can be positioned in-between concepts on the more fundamental level as human rights recognizing "the inherent dignity and of the equal and inalienable rights of all members of the human family" [67] (p. 1), and the concepts on a higher level such as capabilities (or even those towards subjective wellbeing). In the capabilities approach, Sen and Nussbaum [68-70] position freedom as central. This approach refers to values that are related to what human beings are capable of doing, which is argued to expand needs-based approaches [70].

This particular study acknowledges the human needs and wellbeing dimension of sustainability as open-ended. Max-Neef et al. [63] provide a categorization (presenting freedom as a particular need) that may function as a structure to inspire and support conversations on the topic. This categorization functions well in relation to the basic, sufficient and non-overlapping criteria. The HSD approach refers to a fundamental set of different needs, which are claimed to be comprehensive and can be distinguished from one another. The categories have also been proposed and proven useful in various sustainability transition processes (e.g., [71-73]).

\subsection{Ecological Sustainability}

Humanity's long-term wealth is dependent upon ecosystem services, and humanity's influence on nature is now of such magnitude that we have arguably entered a new geological epoch: "the Anthropocene" [74]. Hence, the ecological sustainability dimension has a significant role in conversations on sustainability.

Nature and its interconnectedness with society represent complex systems. From work on socio-ecological resilience, we know that such systems to a large extent are non-linear, unpredictable, uncontrollable, and interdependent $[55,57]$, which suggest caution in society's interaction with nature.

One approach to this insight is to move the focus upstream in causal chains where the complexity is lower. By doing so, the object of focus becomes upstream causes in the societal metabolism rather than the downstream effects in nature. This leads to our overarching question of ecological sustainability: "How can society's activities fit within nature's carrying capacity?" This shifts attention from environmental pathology to societal prevention [34], as what are usually considered to be environmental problems often originate in society. It is therefore of central importance to understand the mechanisms through which society interacts with nature.

We have chosen a contribution of social-ecological indicators as a starting point in this particular study. It builds on two main mechanisms for the physical influence of society on nature: (1) exchange of energy and materials between nature and society and (2) manipulation by displacement or control of subsystems of nature [75].

In the exchange of materials between society and nature it can be concluded that living systems have limited adaptation capacity for systematically increasing concentrations of materials that were earlier stored in the Earth's crust. The same holds for molecules and isotopes that are produced in society.

Manipulation can imply: a displacement of the ecosphere (much of the societal infrastructure has this effect); a reshaping of the structures of the ecosphere (e.g., damming of rivers, ditching, ploughing); and, a guiding of processes and flows (e.g., agricultural practices, manipulation of genes).

These mechanisms were used as a basis to form the categories for ecological sustainability in this study, with the mechanisms of exchange divided into the two categories of "substances from earth's crust" and "substances produced in society", and the mechanism of manipulation referred to as "physical means". 
The choice of these categories focusing on exchange and manipulation early in the causal chain, can be further motivated by their use in the formulation of socio-ecological principles for sustainability (Holmberg, Robèrt, and Eriksson [34] was the first peer-reviewed paper presenting the socio-ecological principles. Before the final publication it was also printed in Holmberg [76]). These principles (also referred to as the system conditions) were spread through the international work of The Natural Step Foundation and have been used in numerous sustainability transition processes at various levels and scales (see further Broman and Robèrt [77] for an overview). The socio-ecological principles were guided by the fact that the space for life on Earth is limited, carrying a general rule to prevent deviations from the natural state that are large in comparison to natural fluctuations. In particular, it can be argued that deviations should at least not be allowed to increase systematically (see $[32,34,76]$ for an exhaustive discussion).

The principles also had in their development the ambition to be basic, non-overlapping, and sufficient. They have also been discussed in relation to some other principles-oriented contributions, including Daly's [78] five principles of sustainable development [34]. Later, they were also compared with other ecological concepts, for instance, factor four [79] and ecological footprint [80].

In this particular study, we do not go as far as to propose certain principles for sustainability. Rather, this study stays with the three mechanisms of substances from earth's crust, substances produced in society, and physical means, as its categories for ecological sustainability.

\section{Method}

This study aims to create a conceptual framework with a set of categories for each sustainability dimension. As the categories for 'human needs and wellbeing', as well as the ecological dimension, have been elaborated upon in the background section, the method section presents how categories were derived for the 'social' and 'economic' sustainability dimension, which is then presented in the results section.

As described in the background, there were no contributions for social or economic sustainability that fulfilled our requirements. We therefore chose to explore these dimensions further in a systematic way through a thematic analysis of prevalent frameworks and conceptualizations.

The method consists of three main processes: (i) a qualitative literature review; (ii) a thematic analysis; and (iii) interpretation and contextualization. The following criteria were adopted to guide the formation of the categories for each sustainability dimension:

- Basic, meaning that each category should reflect basic, upstream 'first-order' properties and mechanisms that are key for the dimension.

- Sufficient, meaning that the categories spanning each dimension should seek to cover all major aspects of the dimension.

- Non-overlapping, meaning that the categories seek internal homogeneity and external heterogeneity [81] to allow for simple comprehension.

\subsection{Thematic Analysis to Arrive at Social and Economic Categories}

The categories were identified through a thematic analysis of established sustainability frameworks. In a thematic analysis, one searches for patterns in a set of data to form groups under joint headings, 'themes' [82-84]. A theme "captures something important about the data in relation to the research question, and represents some level of patterned response or meaning within the data set" [83] (p. 82). The thematic analysis followed three steps of:

1. sample selection and extraction of sustainability aspects,

2. collating aspects into themes, and

3. proposing categories by selecting and structuring themes in relation to criteria: basic, sufficient, and non-overlapping. 
Samples were selected from a previous literature search [85] on frameworks concerning social and economic sustainability. The first two steps of the analysis involved processes of moving forward and backward between the initial data and proposed themes. This process of iteration continued until the point when additional aspects and refinements ceased to yield new themes.

In the third step, the themes were selected and structured in relation to the criteria of being basic, sufficient, and non-overlapping. The non-overlapping criteria was incorporated in the process of theme formulation. By inspecting the themes against the basic criteria, it was possible to restructure and prioritize more fundamental themes. In the test for sufficiency, a set of individual contributions on social and economic sustainability (not part of the initial thematic analysis) was introduced to evaluate the comprehensiveness of the initially proposed themes.

Following this third step, themes were judged to now represent a set of proposed categories, to be interpreted in their respective sustainability context.

\subsection{Interpreting the Social and Economic Categories in the Context of Their Sustainability Dimensions}

In the previous steps, a set of aspects were extracted out of their context, formulated into themes and that are translated into categories in relation to the basic, sufficient, and non-overlapping criteria.

In this final step, the categories were qualitatively explained in relation to their sustainability dimension in order to provide the categories with context and meaning. Formulations were sought after that reflected the categories respecting the balanced approach; i.e., leaving the terms open to invite for conversations of political and normative character, while also inspiring and supporting such conversations.

Section 4 and its subsections present the process of the thematic analysis and the interpretation of the social and economic categories in their sustainability context.

\section{Results-Arriving at a Set of Categories for Social and Economic Sustainability}

This section first presents the thematic analysis of social and economic sustainability, followed by an interpretation of the themes in the context of their respective sustainability dimension.

\subsection{Social Sustainability}

\subsubsection{Sample Selection and Extraction of Social Aspects}

This thematic analysis began by selecting prevalent social sustainability conceptualizations claiming to be comprehensive. These included: two reviews of social sustainability $[2,10]$ and three principles-oriented conceptualizations [18-20]. In addition, principles-oriented conceptualizations were included as initial samples in the thematic analysis, as they are often developed with an aim similar to this particular study. The samples are briefly presented in Table 1.

Table 1. A short description of samples included in the thematic analysis of social sustainability.

\begin{tabular}{cl}
\hline Sample & Short Description the Sample \\
\hline Colantonio [60] & $\begin{array}{l}\text { An exploration of key themes of social sustainability and its } \\
\text { main assessment methods. Traditional ('hard' social policy } \\
\text { areas) and emerging ('softer' research and policy-making } \\
\text { concepts) themes are presented through an analysis of } \\
\text { sustainability assessment documents. }\end{array}$ \\
& $\begin{array}{l}\text { A review of } 20 \text { key policy documents (UN, multilateral, } \\
\text { European) and } 88 \text { research contributions including social } \\
\text { sustainability, green social policy, environmental justice, } \\
\text { ecological modernization and environmental policy } \\
\text { integration. }\end{array}$ \\
\hline Gurphy [61] & $\begin{array}{l}\text { A thematic content analysis of } 14 \text { key policy documents and } \\
\text { research contributions on sustainable development. }\end{array}$ \\
\hline
\end{tabular}


Table 1. Cont.

\begin{tabular}{|c|c|}
\hline Sample & Short Description the Sample \\
\hline Missimer et al. [62] & $\begin{array}{l}\text { A systems approach to identify essential aspects of the social } \\
\text { dimension of sustainability to create a structuring and } \\
\text { coordinating framework represented by a set of } \\
\text { non-overlapping principles. Research contributions from } \\
\text { complex adaptive system studies, human needs theory and } \\
\text { other social sciences were included. }\end{array}$ \\
\hline Statistics New Zealand [86] & $\begin{array}{l}\text { A thematic and procedural approach for sustainable } \\
\text { development, building on the MONET framework from the } \\
\text { Swiss Federal Statistics Office [87]. }\end{array}$ \\
\hline
\end{tabular}

All aspects from the included samples that related to social sustainability were selected. Aspects that bridged social dimensions with other dimensions were also included. The extracted aspects from each sample are presented in Appendix A (Tables A1 and A2).

It is recognized that further conceptualizations of social sustainability exist (e.g., [59-62,86,88-99]). A selection of additional samples, not part of the initial thematic analysis, were introduced at a later stage of the analysis and tested against the criteria of sufficiency-i.e., does the introduction of aspects from additional contributions suggest aspects not reflected in the initially proposed themes?

\subsubsection{Collating Social Aspects into Themes}

In this interim step, the extracted aspects were grouped into themes without any ranking or hierarchical order, guided by the non-overlapping criteria. A first theme was identified covering aspects of cohesion, e.g., "social mixing and cohesion" [60] and "social cohesion" [59,61]. A second theme related to equity, justice, and distribution was identified, e.g., "equity", "social justice" [60], and "allocate in a fair manner benefits and costs ..." [59]. A third theme relating to social relations was identified, e.g., "social capital" [60] and "cultural diversity and identity" [86]. A fourth theme relating to governance and participation was identified, e.g., "governance rights, participation, effectiveness" [86], "participation and access" [61], and "influence" and "impartiality" [62].

A set of aspects identified in the samples on social sustainability related to 'human needs \& wellbeing', e.g., "basic needs" and "well-being" [60], "health" [60,62,86] and "development of individual knowledge and skills" [59]. As the framework that was created in this study has a separate dimension on human needs and wellbeing, these aspects were excluded from the social dimension. A full account on the aspects related to each theme is presented in Appendix B (Tables A3 and A4).

4.1.3. Proposing Social Categories by Selecting and Structuring Social Themes in Relation to Basic, Sufficient and Non-Overlapping Criteria

The proposed themes were then analysed in relation to the basic and sufficient criteria. Four themes were identified in the thematic analysis: (1) social cohesion, (2) social relations, (3) governance/participation, and (4) equity/justice/distribution.

First, it can be identified that social cohesion is a more overarching feature of social sustainability, referring to societies and communities that hold together rather than fall apart [86].

Second, social relations and governance/participation represent two themes that refer to different relational qualities: those between people and those between people and institutions.

The last theme referring to equity/justice/distribution can be considered a specific relational quality and may hence be argued to overlap with the categories of social relations and governance/participation. However, equity and justice are positioned as central concepts in all social sustainability samples. For this reason, this study considers equity and justice as a separate category. 
These themes were tested for sufficiency by contrasting towards contributions on social sustainability not part of the initial thematic analysis. No proposed themes were suggested from these additional frameworks (Appendix C).

\subsubsection{Interpreting the Social Categories in the Context of Social Sustainability}

The overarching theme for social sustainability identified in the thematic analysis is social cohesion, a term that extends beyond the sustainability discourse and is used to refer to functioning societies and social systems at large $[100,101]$. We chose to capture social cohesion with the overarching question "How can we live together"?

Social relations between people, and relations between people and institutions represent two distinct properties of (modern) societies. Central work within sociology and political sciences focuses on these two relations; contributions on social capital emphasizing the former [102-104] and contributions on quality of government emphasizing the latter [105-107].

In work on social capital, trustful relations between people are considered essential 'glues' that hold communities together [102-104]. For societies then, comprising several groups, trustful relations within groups as well as between groups $[108,109]$ can be considered central for social sustainability.

In work on 'quality of government', trustful relations between individuals and institutions (primarily those with delegated power) is argued to be essential for holding societies together. Here, impartial relations (e.g., non-corruption) in the exercise of authority is stressed [105-107,110].

Both inter- and intragenerational justice are prevalent terms in the sustainability discourse. In the social dimension, special attention is paid to the intragenerational aspect, where equity and equality have been identified as important factors contributing to social cohesion [107,111]. However, eventual benefits from just and equal societies do not necessarily need to be motivated towards other ends, but can be considered as intrinsic in their own right $[67,112]$. Here, equity and justice are judged to deserve a category on its own, also due to its central role and prevalence in sustainability (and societal) discourse at large.

Building on the idea of distinguishing horizontal and vertical forms of trust (e.g., [113-115]), this conceptual framework extends/builds upon these terms and proposes the notions of 'horizontal' and 'vertical' relations. The reason for this is to emphasize not only one specific relational quality. These are then complemented with the inclusion of justice/equity, one identified important mechanism in securing the quality of relations.

\subsection{Economic Sustainability}

\subsubsection{Sample Selection and Extraction of Economic Aspects}

The thematic analysis of economic sustainability began with the work of Gagnon et al. [59] and Statistics New Zealand [86], both of which are significant contributions to economic sustainability.

Contributions by Lawn [116] and Anand and Sen [117] (this contribution largely builds upon the work by Robert M. Solow [118]) were also used as samples in the thematic analysis. They both discuss economic sustainability on a fundamental level, which is in line with the aim of this particular study. The samples are briefly presented in Table 2 .

The first three samples $[59,86,116]$ present aspects that are argued to be of central importance for economic sustainability, all of which were extracted. Anand and Sen [117] do not clearly specify key aspects that exist, but discuss economic sustainability from the perspectives of distributional and intergenerational equity (universalism), preserving capital, and enhancing productive capacities. The samples and extracted aspects are presented in Appendix A (Tables A1 and A2). 
Table 2. A short description of samples included in the thematic analysis of economic sustainability.

\begin{tabular}{ll}
\hline Sample & Short Description the Sample \\
\hline Gagnon et al. [59] & $\begin{array}{l}\text { A thematic content analysis of } 14 \text { key policy documents and research } \\
\text { contributions on sustainable development. }\end{array}$ \\
\hline Statistics New Zealand [86] & $\begin{array}{l}\text { A thematic and procedural approach for sustainable development, building } \\
\text { on the MONET framework from the Swiss Federal Statistics Office [87]. }\end{array}$ \\
\hline Lawn [116] & $\begin{array}{l}\text { A representation of the socio-economic process as a means to establish } \\
\text { definitions of sustainable development. The paper includes an analysis of } \\
\text { existing sustainable development indicators, and presents a set of } \\
\text { macro-level indicators (directed towards measuring sustainable } \\
\text { development on a national scale). }\end{array}$ \\
\hline Anand and Sen [117] & $\begin{array}{l}\text { A paper considering economic sustainability a matter of intergenerational } \\
\text { equity, seeking to specify what is to be sustained. It explores the } \\
\text { relationship between factors such as distributional equity, growth and pure } \\
\text { time reference. }\end{array}$ \\
\hline
\end{tabular}

\subsubsection{Collating Economic Aspects into Themes}

In this interim step, the extracted aspects were grouped into themes without any ranking or hierarchical order, guided by the non-overlapping criteria. The first theme identified relates to resource use, e.g., "efficient resource use" [59,86] and "efficiently produced" [116] (Note that this theme relates to resource use, and not efficiency. Resource use is central in concepts like circular economy and should be understood in relation to nature's carrying capacity and human wellbeing. The aspects extracted from the initial samples indeed emphasize efficiency in the use of resources, but efficiency is a concept to be considered with caution. Too strong focus on efficiency can actually contradict the resilience of a system. This has been widely discussed by scholars within sustainability and resilience. Cf. [119] for a thorough discussion). A second theme relates to man-made capital, e.g., "maintain infrastructure" [86] and "human-made capital intact" [116]. Sample [117] also touches upon capital, however this is considered in a broader sense by referring to the issue of preserving capital, without further specifying what kind of capital to consider. A third theme was identified around human capabilities and knowledge, e.g., "preserve/enhance productive capabilities [117] and " ... development of knowledge and skills" [86].

Lastly, a fourth theme was identified on the issue of financial capital and debt, e.g., "limiting the accumulation of debt ... " [86] and the significance of "overseas debt" in determining the long-term capacity of sustaining levels of economic welfare [116]. This also relates to the general call for a long term perspective brought up in several of the contributions, e.g., "long-term investment considering all types of capital" [59], "encouraging a long-term outlook ... ", and " .. options created for current and future generations" [86].

A set of aspects that were identified in the samples on economic sustainability highlight the purpose of the economic sustainability dimension to serve needs, e.g., "organize work and commerce so that every human being can meet their needs" [59] and "economic system meets the needs of society" [86]. This is acknowledged in the way the proposed framework acknowledges 'human needs \& well-being' as a separate sustainability dimension, and that the economic sustainability dimension seeks to serve these ends. Another set of aspects identified in the economic sustainability samples relate to those both handled in the social sustainability dimension, including distributional equity [117] as well as to sustainability at large (intergenerational justice [117]). A full account on the economic aspects related to each theme is presented in Appendix B (Tables A3 and A4). 
4.2.3. Proposing Economic Categories by Selecting and Structuring Economic Themes in Relation to Basic, Sufficient and Non-Overlapping Criteria

It can first be identified that all samples touch upon a similar main issue for economic sustainability; that of managing capital for present and future generations. The samples then discuss various aspects of this issue, both regarding how capital is to be managed, and what capital to consider. As this study does not seek to prescribe "how" capital is to be managed, the selection and structuring process here will circulate around what kind of capital to consider in the economic sustainability dimensions.

Four capitals were identified in the thematic analysis (with the original name of the themes in brackets): (1) natural capital (resource use); (2) man-made capital; (3) human capital (human capabilities and skills); and (4) financial capital (financial capital and debt). These capitals were tested for sufficiency by contrasting towards some other contributions on economic sustainability not part of the initial thematic analysis. No proposed themes were suggested from the additional frameworks (Appendix C).

\subsubsection{Interpreting the Economic Categories in the Context of Economic Sustainability}

As identified in the thematic analysis, the contributions suggest economic sustainability to be an issue of managing capital not only in the present but also for future generations. We chose to capture this with the question: "How can capital be managed for the future?". Capital is here understood broadly as material and immaterial stocks; an asset valuable for present and future generations. In economics, capital is often ascribed with a certain price tag (and ownership). In this study, capital is understood more broadly, to also include that of 'commons' [120], e.g., that may lack a price tag and is accessible for a larger population. The idea of economy as an issue of managing capital can be traced back to the old Greek words on 'economy' and 'economics', from oikonomia - the art of household management, coming from oikonomis, from oikos house + nemein to manage [121]. Aristotle [122] distinguished oikonomía from chrematistics (the art of acquisition). Chrematistics was in turn distinguished in two forms: one related to the oikonomia being external exchange of what was internally produced in excess to acquire necessary use-values, and a second form "which Aristotle saw as secondary from a logical and historical point of view, concerned the 'art of money-making' — accumulation of exchange-values by means of commerce" [123] (p. 369).

The four categories identified in the thematic analysis were natural capital, man-made capital, human capital, and financial capital. The first three capital forms can be identified already in early contributions in economics [124], often referred to as the factors of production being "land" (natural capital), "labour" (human capital), and "capital" (man-made capital) [125]. Apart from the capital stocks part of the economic sustainability dimension, there are also capital 'stocks' part of social sustainability (e.g. social rules and institutions) and ecological sustainability (e.g. ecosystems providing services). These capital stocks deserve their own dimension due to their central importance in sustainable development, in line with UN declarations [48].

Natural capital refers to stocks of natural resources, including energy, matter, and land (space). Energy cannot be created or destroyed but transferred and converted. Rather, it is the exergy that is to be considered when managing energy (exergy can roughly be understood as the quality of energy that actually can be consumed) [126]. Managing matter in sustainable ways is today found in the circular economy discourse $[127,128]$. Here, it is argued that value in matter should not be wasted, and dissipative use should be avoided, e.g., through "closing the loops". The issue of land (space) is not least discussed in the context of urban planning, regarding its efficient and effective use for e.g., transportation systems.

Man-made capital refers to resources that have been built-in society for various functions normally with a longer life time, such as buildings, road infrastructure, and water distribution systems. This also includes stocks of more immaterial character, such as knowledge and information. These stocks 
are, for instance, stored in libraries and databases, not least accumulated in processes of research and innovation.

Human capital refers to the immaterial stocks such as knowledge and skills accumulated by people [129]. Here, education becomes central to how one thinks about and manages a knowledge base. For instance, is education to be considered an investment or a cost?

Financial capital is handled as a separate category, as it plays a significant role in today's economy. Financial capital can take both material (a coin) and immaterial (on the bank account or even as bitcoins) forms. The way it is managed and used can have long-term implications. Here, the issue of investments and debt are critical, as well as whether and how the value of the future is discounted [130].

Often the capital forms need to be considered in parallel. For example, a broad concept such as technology spans various forms of capital. The physical product is man-made, and so is the knowledge behind its functioning embedded in the product and its manuals, while the skills to construct and operate it belong to the human capital.

\section{A Proposed Conceptual Framework}

The conceptual framework resulting from the study is presented in Figure 1. The aim of the framework is to inspire and support conversations on sustainability.

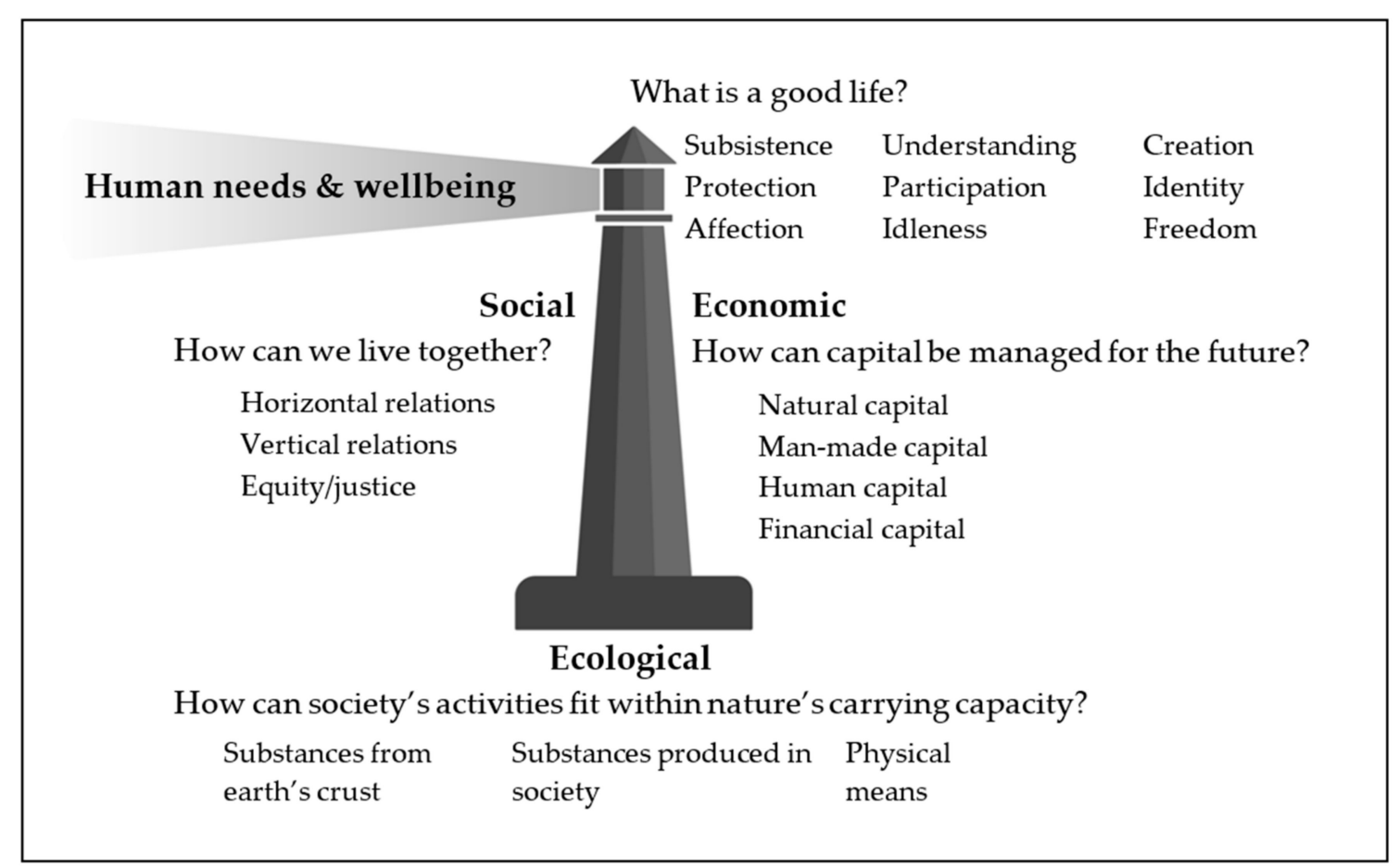

Figure 1. The conceptual framework visualized in a "lighthouse" model aims to inspire and support conversations on sustainable futures. On top of the lighthouse lies the human needs and wellbeing dimension (categories from Max-Neef et al. [63]). Depending on how these needs are met, this dimension influences the other dimensions, and provides direction and purpose. The lighthouse rests on the ecological dimension (categories from Holmberg et al. [34]). The social and economic dimension are understood as structures combining the two other dimensions, and are also in themselves critical for sustainability. The lighthouse might be especially useful in backcasting processes. Needless to say, there are also interdependencies between the dimensions, and to be relevant the categories must continuously be revised.

For pedagogical reasons, the framework is visualized as a lighthouse. It places emphasis on the Brundtland definition by situating the 'human needs and wellbeing' dimension in the light from the beacon. Moreover, it acknowledges that the ecological dimension provides the fundamental basis for 
all human activity by situating the ecological dimension at the bottom. In between the ecological and human needs and wellbeing dimensions lie the social and economic dimensions. Each dimension consists of an introductory overarching question, which is accompanied by a set of categories to guide the conversation on the topic.

\section{Concluding Discussion}

The concluding discussion consist of three parts. Firstly, we discuss and reflect upon the results and main contributions from this study; secondly, we suggest how the results can be used in transition processes; and thirdly, we explore ways forward for related future research.

\subsection{The Sustainability Lighthouse}

We have created a conceptual framework encompassing the social, economic and ecological sustainability dimension together with a dimension on 'human needs \& wellbeing'. This framework is accompanied by a set of overarching questions and categories for each dimension and visualized as a lighthouse, with the aim of inspiring and supporting conversations on sustainable futures.

The ambition was for the categories for each sustainability dimension to be basic, sufficient, and non-overlapping. We also stress that this is by no means to be considered a definitive result; rather, it demands continuous adjustment to be relevant for its time. Not least, since sustainability itself is a moving object.

As presented in the introduction, we sought to identify categories for each sustainability dimension that were balanced; open but still informed. We have, over the course of $20+$ years involvement in sustainable transition processes at various scales, witnessed a demand for a balanced framework of this kind, which leaves the concept of sustainability open enough to invite for conversations of political and normative character, while also providing help in inspiring and supporting such conversations.

We regard our primary contribution to be a set of balanced categories that clarify both the division between the different sustainability dimensions, as well as whether the categories are means or ends. This is for two main reasons. Firstly, in the process of developing the framework, we have seen that other contributions, with similar ambitions of providing a balanced framework, often consist of both means and ends. This can be problematic when the framework should serve as support in conversations, especially when embedded in a backcasting process. Secondly, we have also found that other contributions vary in their description of the social dimension at the level of the individual, the group, or both.

The results generated from this kind of research openly build upon the contributions and understandings of others, rather than developing an entirely new understanding of sustainability. Ideally, the results should be viewed as relevant and almost self-apparent. The process is similar to the saying by Einstein that "everything should be made a simple as possible, but not simpler".

\subsection{The Lighthouse in Sustainability Transition Processes}

We foresee that the lighthouse may be of value in processes guiding socio-technical transitions towards sustainability in three different ways: (1) by attempting to bridge the issue of 'transition' with that of 'sustainability'; (2) as part of a backcasting process; and (3) in modes of transdisciplinary research where relevant actors take part in the conversation.

Firstly, both transitions- and sustainability research share an interest in how systemic change can be guided in sustainable directions. Yet, they have a different primary focus. Transition studies emphasise the understanding of past and present dynamics of change in (unsustainable) socio-technical systems, and how such systems are situated between and interact with 'niches' and 'landscapes' [2-7]. This provides one particular kind of system, but one could as well imagine a focus on socio-ecological systems or other conceptualizations. Sustainability research emphasises the understanding of sustainability, and complex dynamics in coupled human-environment systems [131-133]. Hence, 
the lighthouse can be seen as an attempt to bridge the issue of 'transition' with that of 'sustainability' (Cf. [134]). The lighthouse is conceptually visualized in Figure 2, supporting leadership processes that seek to create transformative momentum in a shared understanding of a sustainable direction.

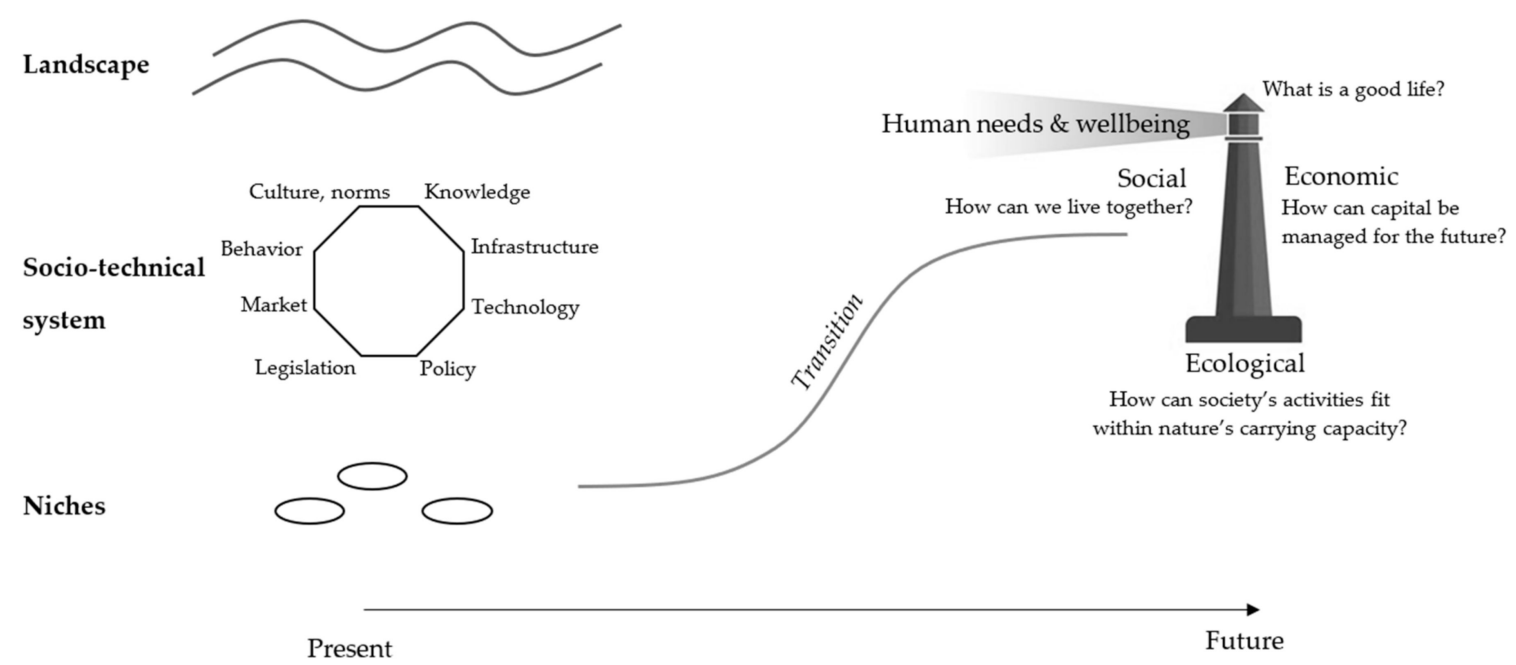

Figure 2. The sustainability lighthouse 'guiding' sustainability transitions in socio-technical systems. To guide transitions in such systems a backcasting from principles approach is suggested. In this approach, the starting point is a conversation on sustainable futures guided by the lighthouse.

Secondly, the lighthouse may function as a tool in backcasting $[31,32,40]$ as a suitable approach to inspire and support conversations on desirable futures. Backcasting was recently recommended by the Sustainable Development Solutions Network for realizing Agenda 2030 and the SDGs [135]. The particular approach to backcasting that this study refers to does not seek to depict the future as images or detailed visions. Rather, we suggest that the lighthouse can foster conversations by directing more focus and attention to the level of principles. These conversations at a principles-level may be beneficial in "staying in the "why' question". It not only supports the construction of a "why" that serves to create a sense of purpose and direction in the process; it also seeks to move the conversations to think beyond today's unsustainable systems. Moreover, the lighthouse within backcasting approaches can function as a basis for shared meaning in the group that builds mutual understanding and improves the coordination of reflexive actions. When the future has been framed in this way (step 1), the next step in the backcasting approach analyses the present situation in relation to the desirable future to identify gaps/challenges (step 2). Then, leverage points can be identified in the gaps where a smaller intervention can have a bigger impact in bridging the gaps (step 3). Finally, strategies are developed for working with the leverage points, e.g., through processes of experimentation (step 4). Note that the four steps presented here demand a preparational phase where the overarching process is designed, actors are invited and the space is set up. Note also that it is often a cyclical process where a broader set of intervention areas are identified in the first backcasting cycle, followed by new backcasting cycles within those areas to identify more specific leverage points. Further, the four steps are not done in isolation. It is, for instance, the combination of abstract guiding principles and concrete experimentation in the present that may trigger transformative momentum towards sustainability. Principles-based approaches thus differ from goals-oriented approaches [136].

Thirdly, we expect that the lighthouse has potential in modes of transdisciplinary research where relevant actors collectively participate in conversations on desirable futures. These conversations typically occur in different contexts, scales, and levels that seek to induce, guide, and accelerate transitions (e.g., communities, organisations, cities, and beyond). Such processes can be considered to lean towards an expedition logic (see introduction), where the question (the challenge) takes the centre stage and relevant actors across sectors are invited to co-create. Divergent views often exist on the roles that research and researchers may play in such societal (sustainability transition) 
processes $[39,137,138]$. It can at least be said that for research to be helpful to the broader society in this context, some level of sensitivity or involvement is needed. Navigating sustainability transitions is a daunting task, often comprising complex, uncertain, and ambiguous processes. Skilful facilitation is key for supporting various actor groups in what can be considered processes of social learning.

Transdisciplinary research [36-39] provides an opportunity for research and practice to engage in modes of co-production to handle complex societal challenges while mutually learning from each other. In transdisciplinary research, knowledge and experience from research as well as practice is valued and flows in both directions. Practice often contains deep contextual insights about present concerns, knowledge of what works, and engagement in real-world processes with (political) legitimacy. Research can provide support by untangling more complex issues, seeking explanations and providing conceptualisations. In our experience, what works best is when practice takes ownership of the real-world process, and research is invited in the role as support and sometimes as facilitators.

\subsection{Future Research}

The lighthouse is developed with the aim of inspiring and supporting conversations on sustainable futures. Different participants benefit from different levels of support. This poses a challenge. When working with the lighthouse, how much is to be served? And how much is to be left open for the participants to construct? Is sequencing the conversation a way forward? By first leaving the conversation open (which may be frustrating for some) and then introducing the lighthouse step-wise to stimulate further conversations? These kinds of issues are typically addressed in work on scaffolding [139].

In general, how conversations on sustainable futures unfold may depend on contextual factors. In the development and evaluation of frameworks such as the lighthouse, it might not necessarily be a question of whether it works or not; rather, guided by the realist evaluation question, it might be a question of "what works, for whom, in what circumstances, in what respect, to what extent and why?" [140]. This opens up for future studies that are related to the lighthouse and results of this study.

To get a sense of one application of the lighthouse, the authors have (involved as facilitators and advisors) recently tested the tentative categories in a strategic backcasting process (owned by the city of Gothenburg, Sweden). It involved actors from the public, private sector, academia, and NGOs focusing on the transition to a sustainable transportation system with a focus on electromobility in Gothenburg. Areas for further research include questions on the usefulness of the framework in such and similar sustainability transition processes. Likely, cross-case analyses could bring extra value to this understanding.

We end this text with a short reminder on Mahatma Gandhi's important role in India's freedom struggle illustrating the power of using guiding principles in transition processes. Gandhi was clear about the guiding principles in the freedom struggle, e.g., equal rights and non-violence. At the same time, he was grounded in applying and testing them. In fact, his autobiography has the sub-title: "The story of my experiments with truth". This dynamic balancing of visionary thinking about guiding principles and the practicing of the same in real life seems to have been a powerful recipe to guide transitions in complex societal systems. The essence is also captured in the quote attributed to Gandhi: "be the change you want to see in the world".

Author Contributions: “Conceptualization, J.H. Methodology, J.L.; Validation, J.H., J.L.; Formal Analysis, J.H., J.L.; Investigation, J.H., J.L.; Resources, J.H., J.L.; Data Curation, J.L.; Writing-Original Draft Preparation, J.H., J.L.; Writing-Review \& Editing, J.H., J.L.; Visualization, J.H., J.L.; Supervision, J.H.; Project Administration, J.H., J.L.; Funding Acquisition, J.H." J.H. presented an earlier version of this paper at the 8th International Sustainability Transitions Conference (IST 2017) in Gothenburg, Sweden.

Funding: This research was funded by Mistra Urban Futures and Region West Sweden.

Acknowledgments: The authors would like to thank Lindsay Berg for assistance in data collection, and Gavin McCrory for cursory reading and constructive comments. The authors would also like to thank Christian Azar, Fredrik Hedenus, Jörgen Larsson, Jonas Nässén, Martin Persson, Niko Schäpke and Frances Sprei for constructive 
comments on earlier drafts of this paper. Finally, the authors would like to thank two anonymous reviewers for their constructive comments on earlier drafts.

Conflicts of Interest: The authors declare no conflict of interest. The funding sponsors had no role in the study.

\section{Appendix A. Conceptualizations Used in the Thematic Analysis}

Table A1. Conceptualizations of social sustainability used in the thematic analysis.

\begin{tabular}{|c|c|c|}
\hline Source & \multicolumn{2}{|c|}{ Aspects } \\
\hline $\begin{array}{l}\text { Colantonio [60] } \\
\text { Social sustainability: a review and } \\
\text { critique of traditional versus emerging } \\
\text { themes and assessment methods }\end{array}$ & $\begin{array}{l}\text { Traditional } \\
\text { Basic needs } \\
\text { Education and skills } \\
\text { Employment } \\
\text { Equity } \\
\text { Human rights and gender } \\
\text { Poverty } \\
\text { Social justice }\end{array}$ & $\begin{array}{l}\text { Emerging } \\
\text { Demographic change } \\
\text { Social mixing and cohesion } \\
\text { Identity, sense of place and culture } \\
\text { Empowerment, participation and } \\
\text { access } \\
\text { Health and Safety } \\
\text { Social capital } \\
\text { Well being, } \\
\text { Happiness and Quality of Life }\end{array}$ \\
\hline $\begin{array}{c}\text { Murphy [61] } \\
\text { The social pillar of sustainable } \\
\text { development: a literature review and } \\
\text { framework for policy analysis }\end{array}$ & $\begin{array}{l}\text { Equity } \\
\text { Awareness for sustainability } \\
\text { Participation } \\
\text { Social cohesion }\end{array}$ & \\
\hline $\begin{array}{c}\text { Gagnon et al. [59] } \\
\text { Sustainable development in } \\
\text { engineering: a review of principles and } \\
\text { definition of a conceptual framework }\end{array}$ & $\begin{array}{l}\text { Social cohesion } \\
\text { Opportunity to mobilize an } \\
\text { Access to ecosystem service } \\
\text { Allocate in a fair manner be } \\
\text { Seek stakeholder involveme } \\
\text { subsidiarity principles }\end{array}$ & $\begin{array}{l}\text { e capabilities } \\
\text { d costs } \\
\text { respecting the accountability and }\end{array}$ \\
\hline $\begin{array}{l}\text { Missimer et al. [62] } \\
\text { A strategic approach to social } \\
\text { sustainability-Part 2: } \\
\text { a principle-based definition }\end{array}$ & $\begin{array}{l}\text { Health } \\
\text { Influence } \\
\text { Competence } \\
\text { Impartiality } \\
\text { Meaning-making }\end{array}$ & \\
\hline $\begin{array}{c}\text { Statistics New Zealand's [86] } \\
\text { framework for measuring sustainable } \\
\text { development }\end{array}$ & $\begin{array}{l}\text { Meet needs } \\
\text { Promote health } \\
\text { Satisfaction and happiness } \\
\text { Equal opportunities and acc } \\
\text { Limits to individual freedor } \\
\text { Development of individual } \\
\text { Governance rights / particip } \\
\text { International development } \\
\text { Historic heritage } \\
\text { Cultural diversity } \\
\text { Cultural identity } \\
\text { Social participation } \\
\text { Integration of disadvantage } \\
\text { (Māori partnership and cult }\end{array}$ & $\begin{array}{l}\text { gources } \\
\text { ge and skills } \\
\text { octiveness } \\
\text { on } \\
\text { tity) }\end{array}$ \\
\hline
\end{tabular}

Table A2. Conceptualizations of economic sustainability used in the thematic analysis.

\begin{tabular}{cl}
\hline Source & \multicolumn{1}{c}{ Aspects } \\
\hline & $\begin{array}{l}\text { Stimulate innovation on a continuous basis to facilitate } \\
\text { the adaptation of the economic system } \\
\text { Maintain a positive, genuine, long term investment } \\
\text { considering all types of capital }\end{array}$ \\
$\begin{array}{c}\text { Gagnon et al. [59] } \\
\text { Ustainable development in engineering: a review of } \\
\text { principles and definition of a conceptual framework } \\
\text { efficient manner }\end{array}$ \\
$\begin{array}{l}\text { Organize work and commerce so that every human being } \\
\text { can meet their needs } \\
\text { Internalize external costs of goods and services with } \\
\text { appropriate environmental and social policies }\end{array}$ \\
\hline
\end{tabular}


Table A2. Cont.

\begin{tabular}{cl}
\hline Source & \multicolumn{1}{c}{ Aspects } \\
\hline & Economic efficiency (overarching) \\
Statistics New Zealand's [86] & Economic system meets the needs of society \\
Maintenance of infrastructure \\
framework for measuring sustainable development & Financial position (debt limitation) \\
& Investment in innovation \\
& Economic efficiency \\
& Development of knowledge and skills to meet the needs \\
& of economic development \\
& Socially compatible rate of change \\
& Promoting resilience in the economic system \\
& World economic activity from which all parties can \\
Lenefit \\
\hline Lawn [116] & Natural capital (maintenance) \\
The sustainability concept and indicators: an introductory & Human-made capital (equitably distributed, efficiently \\
& produced) \\
& Net psychic income (enjoyment of life) \\
& Financial debt \\
\hline Anand and Sen [117] & Distributional and intergenerational equity \\
& (universalism) \\
& Preserving capital \\
& Enhancing productive capacities \\
\hline
\end{tabular}

\section{Appendix B. Sources, Collated Aspects and Proposed Labels}

Table A3. Initially proposed themes, collated aspects and source(s) for the social dimension.

\begin{tabular}{|c|c|c|}
\hline Initial Proposed Theme & Collated Aspects & Source(s) \\
\hline \multirow{2}{*}{ Social cohesion } & Social mixing and cohesion & {$[60]$} \\
\hline & Social cohesion & {$[59,61]$} \\
\hline \multirow{5}{*}{ Equity/justice } & Equity & {$[60,61]$} \\
\hline & Social justice & {$[60]$} \\
\hline & Allocate in a fair manner benefits and costs & [59] \\
\hline & Equal opportunities and access to resources & [86] \\
\hline & Access to ecosystem services & [59] \\
\hline \multirow{6}{*}{ Social relations } & Social capital & [60] \\
\hline & Identity, sense of place and culture & {$[60]$} \\
\hline & Demographic change & {$[60]$} \\
\hline & Historic heritage & [86] \\
\hline & Cultural diversity and identity & [86] \\
\hline & Integration of disadvantaged groups & [86] \\
\hline \multirow{8}{*}{$\begin{array}{c}\text { Governance and } \\
\text { participation }\end{array}$} & Empowerment, participation and access & [60] \\
\hline & Participation & [61] \\
\hline & Seek stakeholder involvement. & [59] \\
\hline & Influence & {$[62]$} \\
\hline & Impartiality & {$[62]$} \\
\hline & Governance rights/participation/effectiveness & [86] \\
\hline & International development cooperation & {$[86]$} \\
\hline & Social participation & [86] \\
\hline \multirow{17}{*}{$\begin{array}{l}\text { Related to human needs } \\
\text { and wellbeing }\end{array}$} & Basic needs & {$[60]$} \\
\hline & Education and skills & {$[60]$} \\
\hline & Employment & {$[60]$} \\
\hline & Human rights and gender & {$[60]$} \\
\hline & Poverty & {$[60]$} \\
\hline & Health and Safety & {$[60]$} \\
\hline & Well-being, happiness and quality of life & {$[60]$} \\
\hline & Awareness & {$[61]$} \\
\hline & Opportunity to mobilize and increase capabilities & [59] \\
\hline & Health & [62] \\
\hline & Competence & {$[62]$} \\
\hline & Meaning-making & {$[62]$} \\
\hline & Meet needs & [86] \\
\hline & Promote health & [86] \\
\hline & Satisfaction and happiness & {$[86]$} \\
\hline & Limits to individual freedom & [86] \\
\hline & Development of individual knowledge and skills & [86] \\
\hline
\end{tabular}


Table A4. Initially proposed themes, collated aspects and source(s) for the economic dimension.

\begin{tabular}{|c|c|c|}
\hline Proposed Theme & Collated Aspects & Source(s) \\
\hline \multirow{4}{*}{ Economic (overarching) } & Economic efficiency & [86] \\
\hline & Promoting resilience ... & {$[86]$} \\
\hline & Preserving capital & [117] \\
\hline & Enhancing productive capacities & [117] \\
\hline \multirow{3}{*}{ Natural resources } & $\begin{array}{l}\text { Use renewable and non-renewable resources in an } \\
\text { efficient manner }\end{array}$ & [59] \\
\hline & Natural capital (maintenance) & [116] \\
\hline & Throughput of matter-energy & [116] \\
\hline \multirow{2}{*}{ Human-made capital } & Maintenance of infrastructure & [86] \\
\hline & $\begin{array}{l}\text { Human-made capital (equitably distributed, } \\
\text { efficiently produced) }\end{array}$ & {$[116]$} \\
\hline \multirow{3}{*}{ Human capital } & $\begin{array}{l}\text { Development of knowledge and skills to meet the } \\
\text { needs of economic development }\end{array}$ & [86] \\
\hline & Stimulate innovation ... & [59] \\
\hline & Investment in innovation & [86] \\
\hline \multirow{4}{*}{ Financial capital } & Internalize external costs of goods and services ... & [59] \\
\hline & $\begin{array}{c}\text {... long term investment considering all types of } \\
\text { capital }\end{array}$ & [59] \\
\hline & Financial position (debt limitation) & [86] \\
\hline & Financial debt & [116] \\
\hline \multirow{4}{*}{$\begin{array}{l}\text { Related to human needs and } \\
\text { wellbeing }\end{array}$} & $\begin{array}{c}\text { Organize work and commerce so that every human } \\
\text { being can meet their needs }\end{array}$ & [59] \\
\hline & Economic system meets the needs of society & [86] \\
\hline & $\begin{array}{l}\text { World economic activity from which all parties can } \\
\text { benefit (needs of nations) }\end{array}$ & [86] \\
\hline & Net psychic income (enjoyment of life) & [116] \\
\hline \multirow{2}{*}{ Related to social sustainability } & Socially compatible rate of change & [86] \\
\hline & Distributional and intergenerational equity & [117] \\
\hline
\end{tabular}

\section{Appendix C. Testing Proposed Social and Economic Themes for Sufficiency}

\section{Appendix C.1. Social Sustainability}

Agyeman and Evans [88] discuss environmental and social justice as central aspects of social sustainability, which in the proposed themes relate to that on equity, justice and distribution.

Cuthill [90] propose social capital, social infrastructure, social justice and equity, and engaged governance as categories. Social capital relates to the proposed theme on social relations. Social infrastructure is operational for providing community needs, hence not considered a basic property here. Social justice relates to the proposed equity/justice theme and engaged governance is covered by the theme on governance/participation.

Littig and Griessler [93] propose satisfaction of basic needs and the quality of life, social justice and social coherence. The first category here relates to the "human needs \& wellbeing" dimension, whereas social justice is covered in the equity/justice theme, and social coherence relates to the overarching idea of social cohesion.

Lehtonen [141] propose capabilities, social capital and institutions as main categories for social sustainability. Here, capabilities relate to the "human needs \& wellbeing" dimension, whereas social capital relates to the social relations, and institutions relates to governance/participation.

\section{Appendix C.2. Economic Sustainability}

Daly [52] proposes manufactured, natural, human and social capital in his model. In the framework proposed in this particular study, social capital relates to the social sustainability dimension. 
Both human and natural capital were identified in the thematic analysis, and manufactured capital belongs to the same category as man-made capital.

Costanza et al. [142] bring forward ecosystem services as flows of materials, energy and information from natural stocks that combined with human and manufactured capital produce human welfare. Here, the fundamental capital flows and stocks referring to are human, manufactured and natural capital—reflecting the three primary capital stocks identified in this particular study.

UN ESCAP [143] presents a framework including manufactured, natural, financial, human (including intellectual) and social capital. These categories are the same as those identified in this particular study, with social capital handled in the social sustainability dimension.

\section{References}

1. United Nations. Transforming Our World: The 2030 Agenda for Sustainable Development; United Nations: New York, NY, USA, 2015.

2. Smith, A.; Voß, J.-P.; Grin, J. Innovation studies and sustainability transitions: The allure of the multi-level perspective and its challenges. Res. Policy 2010, 39, 435-448. [CrossRef]

3. Geels, F.W. The multi-level perspective on sustainability transitions: Responses to seven criticisms. Environ. Innov. Soc. Transit. 2011, 1, 24-40. [CrossRef]

4. Markard, J.; Raven, R.; Truffer, B. Sustainability transitions: An emerging field of research and its prospects. Res. Policy 2012, 41, 955-967. [CrossRef]

5. European Environment Agency. Perspectives on Transitions to Sustainability (No. 25/2017); European Environment Agency: Luxembourg, 2017.

6. Loorbach, D.; Frantzeskaki, N.; Avelino, F. Sustainability transitions research: Transforming science and practice for societal change. Annu. Rev. Environ. Resour. 2017, 42, 599-626. [CrossRef]

7. Geels, F.W. Technological transitions as evolutionary reconfiguration processes: A multi-level perspective and a case-study. Res. Policy 2002, 31, 1257-1274. [CrossRef]

8. Elzen, B.; Geels, F.W.; Green, K. System Innovation and the Transition to Sustainability: Theory, Evidence and Policy; Edward Elgar Publishing: Northampton, MA, USA, 2004.

9. Grin, J.; Rotmans, J.; Schot, J.W. Transitions to Sustainable Development: New Directions in the Study of Long Term Transformative Change; Routledge: New York, NY, USA, 2010.

10. Feola, G. Societal transformation in response to global environmental change: A review of emerging concepts. Ambio 2015, 44, 376-390. [CrossRef] [PubMed]

11. Rotmans, J.; Kemp, R.; Van Asselt, M. More evolution than revolution: Transition management in public policy. Foresight 2001, 3, 15-31. [CrossRef]

12. Reflexive Governance for Sustainable Development; Voss, J.-P.; Bauknecht, D.; Kemp, R. (Eds.) Edward Elgar: Cheltenham, UK; Northampton, MA, USA, 2006.

13. Loorbach, D. Transition Management: New Mode of Governance for Sustainable Development = Transitiemanagement: Nieuwe Vorm van Governance Voor Duurzame Ontwikkeling; Internat Books: Utrecht, The Netherlands, 2007.

14. Loorbach, D. Transition management for sustainable development: A prescriptive, complexity-based governance framework. Governance 2010, 23, 161-183. [CrossRef]

15. Holmberg, J. Olika Aspekter av Agenda 2030-Arbetet; Riksdagens seminarium om Agenda 2030, Rapport från Riksdagen No. 2017/18:RFR21; Riksdagstryckeriet: Stockholm, Sweden, 2018.

16. Smith, A.; Raven, R. What is protective space? Reconsidering niches in transitions to sustainability. Res. Policy 2012, 41, 1025-1036. [CrossRef]

17. Kemp, R.; Schot, J.; Hoogma, R. Regime shifts to sustainability through processes of niche formation: The approach of strategic niche management. Technol. Anal. Strat. Manag. 1998, 10, 175-198. [CrossRef]

18. Stewart, J.M. Future state visioning-A powerful leadership process. Long Range Plan. 1993, 26, 89-98. [CrossRef]

19. Westley, F.; Mintzberg, H. Visionary leadership and strategic management. Strat. Manag. J. 1989, 10, 17-32. [CrossRef]

20. Senge, P. The Fifth Discipline: The Art and Practice of the Learning Organization; Currency Doubleday: New York, NY, USA, 1990. 
21. Berkhout, F.; Smith, A.; Stirling, A. Socio-technological regimes and transition contexts. In System Innovation and the Transition to Sustainability: Theory, Evidence and Policy; Edward Elgar: Cheltenham, UK, 2004; pp. 48-75.

22. Smith, A.; Stirling, A.; Berkhout, F. The governance of sustainable socio-technical transitions. Res. Policy 2005, 34, 1491-1510. [CrossRef]

23. Gibson, R. Should Environmentalists Pursue Sustainable Development? Probe Post 1991, 13, $22-25$.

24. Laws, D.; Scholz, R.W.; Shiroyama, H.; Susskind, L.; Suzuki, T.; Weber, O. Expert views on sustainability and technology implementation. Int. J. Sustain. Dev. World Ecol. 2004, 11, 247-261. [CrossRef]

25. Hopwood, B.; Mellor, M.; O’Brien, G. Sustainable development: Mapping different approaches. Sustain. Dev. 2005, 13, 38-52. [CrossRef]

26. Loorbach, D.; Rotmans, J. The practice of transition management: Examples and lessons from four distinct cases. Futures 2010, 42, 237-246. [CrossRef]

27. Rockström, J.; Steffen, W.; Noone, K.; Persson, A.; Chapin, F.S.; Lambin, E.F.; Lenton, T.F.; Scheffer, M.; Folke, C.; Schellnhuber, H.L.; et al. A safe operating space for humanity. Nature 2009, 461, 472-475. [CrossRef] [PubMed]

28. Jacobs, M. Sustainable development as a contested concept. In Fairness and Futurity: Essays on Environmental Sustainability and Social Justice; Oxford University Press: Oxford, UK, 1999; pp. 21-45.

29. Robinson, J. Squaring the circle? Some thoughts on the idea of sustainable development. Ecol. Econ. 2004, 48, 369-384. [CrossRef]

30. Budwig, N. Concepts and tools from the learning sciences for linking research, teaching and practice around sustainability issues. Curr. Opin. Environ. Sustain. 2015, 16, 99-104. [CrossRef]

31. Robinson, J. Future under glass-A recipe for people who hate to predict. Futures 1990, 22, 820-842. [CrossRef]

32. Holmberg, J.; Robèrt, K.-H. Backcasting from non-overlapping sustainability principles—A framework for strategic planning. Int. J. Sustain. Dev. World Ecol. 2000, 7, 291-308. [CrossRef]

33. Vergragt, P.J.; Quist, J. Backcasting for sustainability: Introduction to the special issue. Technol. Forecast. Soc. Chang. 2011, 78, 747-755. [CrossRef]

34. Holmberg, J.; Robèrt, K.H.; Eriksson, K.-E. Socio-ecological principles for a sustainable society. In Getting Down to Earth-Practical Applications of Ecological Economics; Martinez-Alier, J., Ed.; International Society of Ecological Economics; Island Press: Washington, DC, USA, 1996.

35. Klein, J.T.; Grossenbacher-Mansuy, W.; Häberli, R.; Bill, A.; Scholz, R.W.; Welti, M. (Eds.) Transdisciplinarity: Joint Problem Solving among Science, Technology, and Society. An Effective Way for Managing Complexity; Birkhäuser Basel: Basel, Switzerland, 2001.

36. Klein, J.T. Prospects for transdisciplinarity. Futures 2004, 36, 515-526. [CrossRef]

37. Handbook of Transdisciplinary Research; Hirsch Hadorn, G. (Ed.) Springer: Dordrecht, The Netherlands; London, UK, 2008.

38. Lang, D.J.; Wiek, A.; Bergmann, M.; Stauffacher, M.; Martens, P.; Moll, P.; Thomas, C.J. Transdisciplinary research in sustainability science: Practice, principles, and challenges. Sustain. Sci. 2012, 7, 25-43. [CrossRef]

39. Scholz, R. The Normative Dimension in Transdisciplinarity, Transition Management, and Transformation Sciences: New Roles of Science and Universities in Sustainable Transitioning. Sustainability 2017, 9, 991. [CrossRef]

40. Dreborg, K.H. Essence of backcasting. Futures 1996, 28, 813-828. [CrossRef]

41. Holmberg, J. Backcasting: A Natural Step in Operationalising Sustainable Development. Greener Manag. Int. 1998, 23, 30-51.

42. Robinson, J.; Burch, S.; Talwar, S.; O'Shea, M.; Walsh, M. Envisioning sustainability: Recent progress in the use of participatory backcasting approaches for sustainability research. Technol. Forecast. Soc. Chang. 2011, 78, 756-768. [CrossRef]

43. Larsson, J.; Holmberg, J. Learning while creating value for sustainability transitions: The case of Challenge Lab at Chalmers University of Technology. J. Clean. Prod. 2018, 172, 4411-4420. [CrossRef]

44. WCED. Report of the World Commission on Environment and Development: Our Common Future; United Nations: Oslo, Norway, 1987.

45. Waas, T.; Hugé, J.; Verbruggen, A.; Wright, T. Sustainable Development: A Bird's Eye View. Sustainability 2011, 3, 1637-1661. [CrossRef] 
46. Robinson, J.; Francis, G.; Legge, R.; Lerner, S. Defining a sustainable society. Values Principles and Definitions. Altern. J. 1990, 17, 36-46.

47. UNCED. The Rio Declaration on Environment and Development. In Proceedings of the United Nations Conference on Environment and Development, Rio de Janeiro, Brazil, 3-14 June 1992; United Nations: New York, NY, USA, 19 June 1992.

48. United Nations. Report of the World Summit on Sustainable Development: Johannesburg, South Africa, 26 August-4 September 2002; United Nations: New York, NY, USA, 2002.

49. Meadowcroft, J. Sustainable Development: A New(Ish) Idea for a New Century? Political Stud. 2000, 48, 370-387. [CrossRef]

50. Pieterse, E. Recasting Urban Sustainability in the South. Development 2011, 54, 309-316. [CrossRef]

51. Soini, K.; Birkeland, I. Exploring the scientific discourse on cultural sustainability. Geoforum 2014, 51, $213-223$. [CrossRef]

52. Daly, H.E. Toward a Steady-State Economy; W. H. Freeman and Company: San Francisco, CA, USA, 1973.

53. Meadows, D.H. Indicators and Information Systems for Sustainable Development; The Sustainability Institute: Hartland Four Corners, VT, USA, 1998.

54. AtKisson, A.; Hatcher, R.L. Compass Index of Sustainability: Prototype for a comprehensive sustainability information system. J. Environ. Assess. Policy Manag. 2001, 3, 509-532.

55. Holling, C.S. Resilience and Stability of Ecological Systems. Annu. Rev. Ecol. Syst. 1973, 4. [CrossRef]

56. Adger, W.N. Social and ecological resilience: Are they related? Prog. Hum. Geogr. 2000, 24, 347-364. [CrossRef]

57. Folke, C.; Carpenter, S.; Elmqvist, T.; Gunderson, L.; Holling, C.; Walker, B. Resilience and Sustainable Development: Building Adaptive Capacity in a World of Transformations. Ambio 2002, 31, 437-440. [CrossRef] [PubMed]

58. Walker, B.; Holling, C.S.; Carpenter, S.R.; Kinzig, A.P. Resilience, Adaptability and Transformability in Social-ecological Systems. Ecol. Soc. 2004, 9. [CrossRef]

59. Gagnon, B.; Leduc, R.; Savard, L. Sustainable development in engineering: A review of principles and definition of a conceptual framework. Environ. Eng. Sci. 2009, 26, 1459-1472. [CrossRef]

60. Colantonio, A. Social sustainability: A review and critique of traditional versus emerging themes and assessment methods. In SUE-Mot Conference 2009: Second International Conference on Whole Life Urban Sustainability and Its Assessment: Conference Proceedings; Horner, M., Price, A., Bebbington, J., Emmanuel, R., Eds.; Loughborough University: Loughborough, UK, 2009; pp. 865-885.

61. Murphy, K. The social pillar of sustainable development: A literature review and framework for policy analysis. Sustain. Sci. Pract. Policy 2012, 8, 15-29. [CrossRef]

62. Missimer, M.; Robèrt, K.-H.; Broman, G. A strategic approach to social sustainability-Part 2: A principle-based definition. J. Clean. Prod. 2017, 140, 42-52. [CrossRef]

63. Max-Neef, M.; Elizalde, A.; Hopenhayn, M.; Herrera, F.; Zemelman, H.; Jataba, J.; Weinstein, L. Human Scale Development. Development Dialogue; Cepaur-Dag Hammarskjöld Foundation: Uppsala, Sweden, 1989.

64. Cruz, I.; Stahel, A.; Max-Neef, M. Towards a systemic development approach: Building on the Human-Scale Development paradigm. Ecol. Econ. 2009, 68, 2021-2030. [CrossRef]

65. Maslow, A.H. A theory of human motivation. Psychol. Rev. 1943, 50, 370-396. [CrossRef]

66. Doyal, L.; Gough, I. A Theory of Human Need; Guilford Press: New York, NY, USA, 1991.

67. United Nations. United Nations Universal Declaration of Human Right; UN General Assembly: New York, NY, USA, 1985.

68. Sen, A. A sociological approach to the measurement of poverty: A reply to Professor Peter Townsend. Oxf. Econ. Pap. 1948, 37, 669-676. [CrossRef]

69. Nussbaum, M.C. Women and Human Development: The Capabilities Approach; Cambridge University Press: Cambridge, UK, 2001.

70. Sen, A. The Ends and Means of Sustainability. J. Hum. Dev. Capab. 2013, 14, 6-20. [CrossRef]

71. James, S.; Lahti, T. The Natural Step for Communities: How Cities and Towns Can Change to Sustainable Practices; New Society Publishers: Gabriola Island, BC, Canada, 2009.

72. Wittmayer, J.; Van Steenbergen, F.; Quist, J.; Loorbach, D.; Hoogland, C. The Community Arena: A Co-Creation Tool for Sustainable Behaviour by Local Communities; Methodological Guidelines. Deliverable 4.1 InContext: EU ENV.2010.4.2.3-1; European Union: Brussels, Belgium, 2011. 
73. Jolibert, C.; Paavola, J.; Rauschmayer, F. Addressing Needs in the Search for Sustainable Development: A Proposal for Needs-Based Scenario Building. Environ. Values 2014, 23, 29-50. [CrossRef]

74. Crutzen, P.J. Geology of mankind. Nature 2002, 415, 23. [CrossRef] [PubMed]

75. Holmberg, J.; Karlsson, S. On designing socio-ecological indicators. In Society and Environment: A Swedish Research Perspective; Svedin, U., Hägerhäll-Aniansson, B., Eds.; Kluwer Academic Publishers: Dordrecht, The Netherlands, 1992.

76. Holmberg, J. Socio-Ecological Principles and Indicators for Sustainability. Ph.D. Thesis, Chalmers University of Technology, Gothenburg, Sweden, 1995.

77. Broman, G.I.; Robèrt, K.-H. A framework for strategic sustainable development. J. Clean. Prod. 2017, 140, 17-31. [CrossRef]

78. Daly, H.E. Toward some operational principles of sustainable development. Ecol. Econ. 1990, 2, 1-6. [CrossRef]

79. Robèrt, K.H.; Holmberg, J.; Von Weizsäcker, E.U. Factor X for subtle policymaking-Objectives, potentials and obstacles. Greener Manag. Int. 2000, 31, 25-38.

80. Holmberg, J.; Lundqvist, U.; Robèrt, K.-H.; Wackernagel, M. The ecological footprint from a systems perspective of sustainability. Int. J. Sustain. Dev. World Ecol. 1999, 6, 17-33. [CrossRef]

81. Patton, M.Q. Qualitative Evaluation and Research Methods, 2nd ed.; Sage Publications: Thousand Oaks, CA, USA, 1990.

82. Aronson, J. A pragmatic view of thematic analysis. Qual. Rep. 1995, 2, 1-3.

83. Braun, V.; Clarke, V. Using thematic analysis in psychology. Qual. Res. Psychol. 2006, 3, 77-101. [CrossRef]

84. Fereday, J.; Muir-Cochrane, E. Demonstrating rigor using thematic analysis: A hybrid approach of inductive and deductive coding and theme development. Int. J. Qual. Methods 2006, 5, 80-92. [CrossRef]

85. Holmberg, J.; Larsson, J. A principles-based framework (SF4) for sustainability transitions. In Proceedings of the 8th International Sustainability Transitions Conference, Gothenburg, Sweden, 18-21 June 2017.

86. Statistics New Zealand. Statistics N. Z.'s Framework for Measuring Sustainable Development. 2009. Available online: http://www.stats.govt.nz/publications/nationalaccounts / framework-measuringsustainable-development.aspx (accessed on 30 June 2018).

87. Swiss Federal Statistics Office (SFSO); Swiss Agency for the Environment, Forests and Landscape (SAEFL); Swiss Federal Office for Spatial Development (ARE). Monitoring Sustainable Development. MONET_Final Report, Methods and Results; No. 633-0400-05; SFSO: Neuchâtel, Switzerland, 2004.

88. Agyeman, J.; Evans, B. 'Just sustainability': The emerging discourse of environmental justice in Britain? Geogr. J. 2004, 170, 155-164. [CrossRef]

89. Boström, M. A missing pillar? Challenges in theorizing and practicing social sustainability: Introduction to the special issue. Sustain. Sci. Pract. Policy 2012, 8, 3-14. [CrossRef]

90. Cuthill, M. Strengthening the 'social' in sustainable development: Developing a conceptual framework for social sustainability in a rapid urban growth region in Australia. Sustain. Dev. 2010, 18, 362-373. [CrossRef]

91. De Montmollin, A.; Scheller, A. MONET indicator system: The Swiss road to measuring sustainable development. Int. J. Sustain. Dev. 2007, 10, 61-72. [CrossRef]

92. Dillard, J.; Dujon, V.; King, M. (Eds.) Understanding the Social Dimension of Sustainability; Routledge: New York, NY, USA, 2009.

93. Littig, B.; Griessler, E. Social sustainability: A catchword between political pragmatism and social theory. Int. J. Sustain. Dev. 2005, 8, 65-79. [CrossRef]

94. Missimer, M.; Robèrt, K.-H.; Broman, G. A strategic approach to social sustainability-Part 1: Exploring the social system. J. Clean. Prod. 2017, 140, 32-41. [CrossRef]

95. Pawłowski, A. How many dimensions does sustainable development have? Sustain. Dev. 2008, 16, 81-90. [CrossRef]

96. Seghezzo, L. The five dimensions of sustainability. Environ. Politics 2009, 18, 539-556. [CrossRef]

97. Swiss Federal Statistical Office (SFSO); Swiss Agency for the Environment, Forests and Landscape (SAEFL); Swiss Federal Office for Spatial Development (ARE). Sustainable Development in Switzerland-Indicators and Comments; No. 520-0400; SFSO: Neuchâtel, Switzerland, 2004.

98. Vallance, S.; Perkins, H.C.; Dixon, J.E. What is social sustainability? A clarification of concepts. Geoforum 2011, 42, 342-348. [CrossRef] 
99. Vifell, Å.C.; Soneryd, L. Organizing matters: How 'the social dimension' gets lost in sustainability projects. Sustain. Dev. 2012, 20, 18-27. [CrossRef]

100. Gilbert, R.; Stevenson, D.; Girardet, H.; Stren, R. Making Cities Work: The Role of Local Authorities in the Urban Environment; Earthscan: London, UK, 1996.

101. Larsen, C.A. The Rise and Fall of Social Cohesion: The Construction and De-Construction of Social Trust in the US, UK, Sweden and Denmark; Oxford University Press: Oxford, UK, 2013.

102. Putnam, R.D. Bowling Alone: The Collapse and Revival of American Community; Simon and Schuster: New York, NY, USA, 2000.

103. Coleman, J.S. Foundations of Social Theory; Belknap Press: Cambridge, UK, 1990.

104. Fukuyama, F. Trust: The Social Virtues and the Creation of Prosperity; Free Press: New York, NY, USA, 1995.

105. Rothstein, B. Social Traps and the Problem of Trust; Cambridge University Press: Cambridge, UK; New York, NY, USA, 2005.

106. Rothstein, B.; Teorell, J. What is quality of government? A theory of impartial government institutions. Governance 2008, 21, 165-190. [CrossRef]

107. Rothstein, B.; Uslaner, E.M. All for all. Equality, Corruption and Social Trust. World Politics 2005, 58, 41-72. [CrossRef]

108. Etzioni, A. Is Bowling together Sociologically Lite? Contemp. Sociol. 2001, 30, 223-224. [CrossRef]

109. Alexander, J.C. The Civil Sphere; Oxford University Press: New York, NY, USA, 2006.

110. Rose-Ackerman, S. Global Crises, Global Solutions. In Governance and Corruption; Lomborg, B., Ed.; Cambridge University Press: Cambridge, UK, 2004.

111. Wilkinson, R.; Pickett, K. The Spirit Level. Why Greater Equality Makes Societies Stronger; Penguin: London, UK, 2010.

112. Rawls, J. A Theory of Justice; Harvard University Press: Cambridge, MA, USA, 1971.

113. Braithwaite, V.; Levi, M. (Eds.) Trust and Governance; Russell Sage Foundation: New York, NY, USA, 1998.

114. Putnam, R.D. What makes democracy work? Natl. Civ. Rev. 1993, 82, 101-107. [CrossRef]

115. Eek, D.; Rothstein, B. Exploring a Causal Relationship between Vertical and Horizontal Trust. 2005. Available online: https://gupea.ub.gu.se/bitstream/2077/39200/1/gupea_2077_39200_1.pdf (accessed on 30 August 2018).

116. Lawn, P. The sustainable development concept and indicators: An introductory essay. Int. J. Environ. Sustain. Dev. 2004, 3, 199-234. [CrossRef]

117. Solow, R.M. Sustainability: An economist's perspective. In The Eighteenth J. Seward Johnson Lecture; Woods Hole Onceanographic Institution: Woods Hole, MA, USA, 1991.

118. Anand, S.; Sen, A. Human development and economic sustainability. World Dev. 2000, 28, $2029-2049$. [CrossRef]

119. Ulanowicz, R.E.; Goerner, S.J.; Lietaer, B.; Gomez, R. Quantifying sustainability: Resilience, efficiency and the return of information theory. Ecol. Complex. 2009, 6, 27-36. [CrossRef]

120. Origin and Etymology of Economy. Merriam-Webster Online. Available online: https://www.merriamwebster.com/dictionary / economy (accessed on 30 June 2018).

121. Aristotle. Aristotle's Politics; Clarendon Press: Oxford, UK, 1967.

122. Stahel, A.W. Complexity, oikonomía and political economy. Ecol. Complex. 2006, 3, 369-381. [CrossRef]

123. Ostrom, E. Governing the Commons; Cambridge University Press: Cambridge, UK, 2015.

124. Marshall, A. Principles of Economics, 8th ed.; Macmillan and Co.: London, UK, 1920.

125. Samuelson, P.A.; Nordhaus, W.D. Economics, 19th ed.; McGraw-Hill Irwin: Boston, MA, USA, 2010.

126. Wall, G. Exergy: A Useful Concept. Ph.D. Thesis, Chalmers University of Technology and University of Gothenburg, Gothenburg, Sweden, 1986.

127. Pearce, D.; Turner, R. Economics of Natural Resources and the Environment; John Hopkins University Press: Baltimore, MD, USA, 1989.

128. Geissdoerfer, M.; Savaget, P.; Bocken NM, P.; Hultink, E.J. The Circular Economy-A new sustainability paradigm? J. Clean. Prod. 2017, 143, 757-768. [CrossRef]

129. Becker, G.S. Human capital revisited. In Human Capital: A Theoretical and Empirical Analysis with Special Reference to Education, 3rd ed.; The University of Chicago Press: Chicago, IL, USA, 1994; pp. 15-28.

130. Azar, C.; Sterner, T. Discounting and distributional considerations in the context of global warming. Ecol. Econ. 1996, 19, 169-184. [CrossRef] 
131. Kates, R.W.; Clark, W.C.; Corell, R.J. Sustainability Science. Science 2001, 292, 641-642. [CrossRef] [PubMed]

132. Miller, T.R.; Wiek, A.; Sarewitz, D.; Robinson, J.; Olsson, L.; Kriebel, D.; Loorbach, D. The future of sustainability science: A solutions-oriented research agenda. Sustain. Sci. 2014, 9, 239-246. [CrossRef]

133. Bai, X.; Van der Leeuw, S.; O’Brien, K.; Berkhout, F.; Biermann, F.; Brondizio, E.S.; Syvitski, J. Plausible and desirable futures in the Anthropocene: A new research agenda. Glob. Environ. Chang. 2016, 39, 351-362. [CrossRef]

134. Schäpke, N. Linking Transitions to Sustainability: Individual Agency, Normativity and Transdisciplinary Collaborations in Transition Management. Ph.D. Thesis, Leuphana University of Luneburg, Luneburg, Germany, 2018.

135. SDSN. Getting Started with the Sustainable Development Goals-A Guide for Stakeholders. 2015. Available online: https: / /sdg.guide/ (accessed on 30 June 2018).

136. Patton, M.Q. Principles-Focused Evaluation; Guilford: New York, NY, USA, 2017.

137. Miller, T.R. Constructing sustainability science: Emerging perspectives and research trajectories. Sustain. Sci. 2013, 8, 279-293. [CrossRef]

138. Wittmayer, J.M.; Schäpke, N. Action, research and participation: Roles of researchers in sustainability transitions. Sustain. Sci. 2014, 9, 483-496. [CrossRef]

139. Van de Pol, J.; Volman, M.; Beishuizen, J. Scaffolding in Teacher-Student Interaction: A Decade of Research. Educ. Psychol. Rev. 2010, 22, 271-296. [CrossRef]

140. Pawson, R.; Tilley, N. Realistic Evaluation; Sage: London, UK; New Delhi, India, 1997.

141. Lehtonen, M. The environmental-social interface of sustainable development: Capabilities, social capital, institutions. Ecol. Econ. 2004, 49, 199-214. [CrossRef]

142. Costanza, R.; D'Arge, R.; De Groot, R.; Farber, S.; Grasso, M.; Hannon, B.; Van den Belt, M. The value of the world's ecosystem services and natural capital. Nature 1997, 387, 253-260. [CrossRef]

143. United Nations' Economic and Social Commission for Asia and the Pacific (ESCAP). Integrating the Three Dimensions of Sustainable Development: A Framework and Tools; ESCAP: Bangkok, Thailand, 2015.

(C) 2018 by the authors. Licensee MDPI, Basel, Switzerland. This article is an open access article distributed under the terms and conditions of the Creative Commons Attribution (CC BY) license (http:/ / creativecommons.org/licenses/by/4.0/). 